\title{
LOUIS $\mathrm{x}$
}

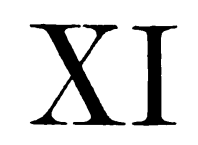

F.T

\section{LA SUCCESSION DE PROVENCE}

- Mémoire lu à l'Académie des Inscriptions et Belles-Lettres

PAR

M. A. LFCOY DHE LA MARCHE

\footnotetext{
PARIS

LIBRAIRIE DE VIGTOIR PALME, ÉDITEUR

76, rue des saints-lises, 76

1888
} 